\title{
Polikistik Over Sendromu ve Ağırlık Yönetimi Arasındaki İlișkinin İncelenmesi
}

\author{
Investigation of the Relationship between Polycystic Ovary \\ Syndrome and Weight Management
}

\author{
Burcu Merve AKSU1두 , Esra Tansu SARIYER ${ }^{2 *}{ }^{\circ}$
}

1Demiroğlu Bilim Üniversitesi Sağlık Bilimleri Fakültesi Beslenme ve Diyetetik Bölümü, İstanbul

2Üsküdar Üniversitesi Sağlık Bilimleri Fakültesi Beslenme ve Diyetetik Bölümü, İstanbul

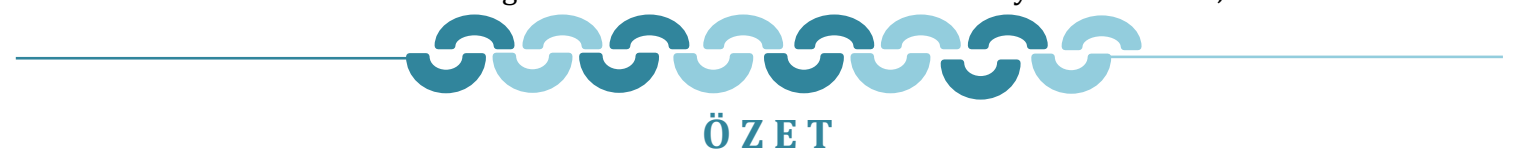

Polikistik over sendromu (PKOS) üreme çağındaki kadınlarda en sık görülen endokrin metabolik bozukluklardan biri olup tanımlanması zor heterojen bir hastalıktır. Etiyolojisi tam olarak bilinmemektedir. Semptomları hiperandrojenizm, hirsutizm, akne, amenore, oligoamenoredir. Prevalansı \%6,5-8 arasında değișmektedir Polikistik over sendromu obezite, insülin direnci, diyabet ve dislipidemi gibi metabolik bozukluklarla ilişkilidir. Polikistik over sendromunda insülin direnci prevalansı \%50-75 aralığında değișmekle beraber, bu bireylerde diyabet başlangıç yaşı sağlıklı bireylere göre 10 yaş daha erkendir. Obezite genellikle abdominal obezite olarak görülür ve PKOS'lu kadınların yaklaşık \%50'sini etkilemektedir. İnsülin direnci ve abdominal obezite PKOS'ta metabolik bozukluk gelişme riskini arttırmaktadır. Polikistik over sendromlu bireylerde birincil tedavi yaklaşımı tıbbi beslenme tedavisi ve egzersizi içeren yaşam tarzı müdahalesidir. Polikistik over sendromu tanılı kadınların izokalorik beslenme planı uygulamalarına rağmen PKOS tanılı olmayan kadınlara göre yüksek beden kütle indeksi (BKİ) değerine sahip olmaları ile birlikte sağlıklı BKİ aralığındaki kadınlarda da vücut yağ yüzdesi değerlendirmesine göre obezite görülebilmektedir. Bu nedenle, tıbbi beslenme tedavisi yaklaşımlarının vücut ağırlığı kaybını hedefleyici olması gerekmektedir. Tıbbi beslenme tedavisi olarak; şeker ve rafine karbonhidratların tüketiminin sınırlandırılması, düşük glisemik indeksli besinlerin tüketilmesi, doymuş ve trans yağ alımının azaltılması ile birlikte D vitamini, krom, inositol ve omega-3 yağ asitlerinden zengin yeterli ve dengeli bir beslenme önerilmektedir. Günlük alınan enerjinin \%55'inin karbonhidratlardan, \%15'inin proteinlerden sağlanması ile birlikte yağ alımının \%30 ile sınırlandırılması önerilmektedir. Polikistik over sendromunda vücut ağırlığı kaybı ve kaybedilen ağırlığın korunması zorlaşmaktadır. Bu nedenle tıbbi beslenme tedavisinde diyete uyumun değerlendirilmesi önemlidir. Bu çalışmada PKOS tanılı kadınlarda yaygın olarak görülen obezite ve komorbid hastalıklar ile vücut ağırlığı yönetimi ilişkisi incelenmesi amaçlanmıștır.

Anahtar Kelimeler: Ağırlık yönetimi, İnsülin direnci, Polikistik over sendromu, Obezite.

Alınış / Received: 05.01.2021 Kabul / Accepted: 06.04.2021 Online Yayınlanma / Published Online: 15.08.2021

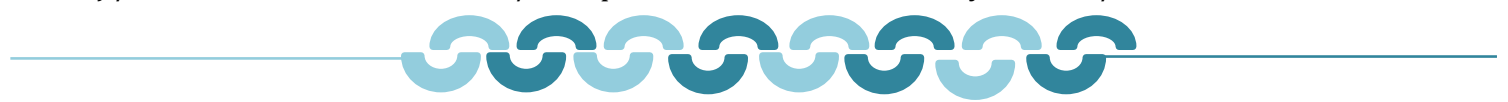

A B S T R A C T

Polycystic ovary syndrome (PCOS) is one of the most common endocrine metabolic disorders in women of reproductive age and is a heterogeneous disease that is difficult to define. Its etiology is unknown. Its symptoms are hyperandrogenism, hirsutism, acne, amenorrhea, oligoamenorrhea. Its prevalence varies between 6.5-8\%. Polycystic ovary syndrome is associated with metabolic disorders such as obesity, insulin resistance, diabetes, and dyslipidemia. Although the prevalence of insulin resistance in PCOS varies between 50-75\%, the age of onset of diabetes in these individuals is 10 years earlier than in healthy individuals. Obesity is generally seen as abdominal obesity and affects approximately $50 \%$ of women with PCOS. Insulin resistance and abdominal obesity increase the risk of metabolic disorders in PCOS. The primary treatment approach for individuals with PCOS is lifestyle intervention, including medical nutrition therapy and exercise. Although women diagnosed with PCOS have an isocaloric diet plan, they have a higher body mass index (BMI) than women without PCOS, and obesity can be seen in women with a healthy BMI according to body fat percentage assessment. Therefore, medical nutrition therapy approaches should be targeting body weight loss. As a medical nutrition therapy; An adequate and balanced diet rich in vitamin $\mathrm{D}$, chromium, inositol and omega-3 fatty acids is recommended, along with limiting the consumption of sugar and refined carbohydrates, consuming low glycemic index foods, reducing saturated and trans fat intake. It is recommended to limit fat intake to $30 \%$, with $55 \%$ of the daily energy taken from carbohydrates and 15\% from proteins. In PCOS, body weight loss and maintaining the lost weight become difficult. Therefore, it is important to evaluate compliance with diet in medical nutrition treatment. In this study, it was aimed to examine the relationship between obesity and comorbid diseases, which are common in women with PCOS, and body weight management.

Keywords: Weight management, Insulin resistance, Polycystic ovary syndrome, Obesity. 
1. Giriş

Doğurganlık çağındaki kadınlarda sık görülen endokrin bir bozukluk olan PKOS, hormonal ve metabolik anomalilere bağlı olarak oluşmaktadır. Bu sendromda androjen hormon yüksekliği, düzensiz menstruasyon ve insülin direnci genellikle görülmektedir. (1,2). Androjen hormon yüksekliğine bağlı olarak hirsutizm, akne, amenore, oligoamenore gibi semptomları vardır (3-5). Dünyada her 16 kadından birinde görülen PKOS, kadınlarda obezite ve hafif şişmanlık görülme oranını artırmaktadır $(6,7)$. Obezite, bu sendromdaki kadınların \%50'sini etkilemektedir (8). PKOS hastalarında ağırlık kontrolü sağlanması hastalığın semptomlarının hafiflemesi ve komorbid hastalıkların riskini azaltmada büyük önem taşımaktadır. Bununla ilişkili olarak makalenin amacı; PKOS hastalarında obezite ve komorbid hastalıkların sıklıkla görülmesi ile ilişkili olarak ağırlık yönetimi ilişkisini incelemektedir.

\section{Polikistik Over Sendromu}

Polikistik over sendromu overlerde disfonksiyon, hiperandrojenizm, hirsutizm, akne, infertilite, alopesi ve gebelik kayıpları gibi klinik durumlardan oluşan bir sendromdur $(9,10)$. Obezite, insülin direnci ve dislipidemi gibi metabolik bozukluklarla ilişkili olan PKOS; uzun dönemde psikososyal sorunlar, tip 2 diyabet, kardiyovasküler hastalıklar ve endometrium kanseri açısından risk oluşturmaktadır $(4,11,12)$. Kapsamlı bir klinik değerlendirme, PKOS'lu tüm kadınlarda BKİ, bel çevresi, kan basıncı, serum lipit ve glukoz seviyelerinin ölçülmesini içermelidir (12). Polikistik over sendromunun etiyolojisi tam olarak bilinmemektedir (13). Adiponektin gen polimorfizmi, düşük doğum ağırlığı, insülin direnci, hiperandrojenizm ve artmış adipozite ile ilişkili olduğu düşünülmektedir (13-16).

Polikistik over sendromu tanısının konulmasında sendromu tanımlayan tek bir anomali veya tanı testi olmadığı için tanımlanması zor heterojen bir hastalıktır (7). Tanıda farklı kriterler kullanılmaktadır. 2012 National Institutes of Health (NIH) konsensusunda, 2003 Rotterdam kriterlerinin kullanımı (Tablo 1) ve fenotiplerin (Tablo 2) tanımlanması kararı verilmiştir (17).

Tablo 1. Polikistik over sendromu tanı kriterleri (17)

\begin{tabular}{|c|c|c|c|}
\hline & 1990 NIH & $\begin{array}{l}2003 \text { Rotterdam } \\
\text { (ESHRE*/ASRM**) }^{* *}\end{array}$ & 2006 AE-PCOS Society*** \\
\hline Kriterler & $\begin{array}{l}\text {-Hiperandrojenizm } \\
\text {-Oligoamonere } \\
\text { *2 kriterin ikisinin de olması } \\
\text { istenmektedir. }\end{array}$ & $\begin{array}{l}\text { - Hiperandrojenizm } \\
\text { - Oligoamonere } \\
\text { - Polikistik over morfolojisi } \\
\text { * } 3 \text { kriterinin ikisinin olması } \\
\text { istenmektedir. }\end{array}$ & $\begin{array}{l}\text { - Hiperandrojenizm } \\
\text { - Over disfonksiyonu } \\
\text { (Oligoamonere veya } \\
\text { polikistik over morfolojisi } \\
\text { veya her ikisinin olması) } \\
\text { *2 kriterinin ikisinin de } \\
\text { olması istenmektedir. }\end{array}$ \\
\hline
\end{tabular}

*ESHRE: European Society for Human Reproduction \& Embryology.

**ASRM: American Society of Reproductive Medicine.

***AE-PCOS: Androgen Excess \& PCOS

Üreme çağındaki kadınlarda en sık görülen endokrinopati olan PKOS, kadınları \%6,5-8 oranında etkilemektedir (9). Hastalığın prevalansı ile ilgili literatürde farklı değerlendirmeler mevcuttur. Bozdağ ve ark. farklı ülkelerde PKOS prevalansının incelendiği meta-analizinde \%8-13 (1), Amerika Birleşik Devletleri'nde yapılan bir çalışmada \%6,6 (18) ve Kite ve ark. PKOS'ta egzersiz ve tıbbi beslenme tedavisi yönetimi ile ilgili sistematik derleme ve metanalizinde ise \%6-21 (16) olarak bildirilmektedir. Bir metaanalizde \%6-10 arasında belirlenen PKOS prevalansının ekonomik kalkınma ile artma eğiliminde olduğu bildirilmiştir (14). Polikistik over sendromu görülme oranı etnik kökenlere bağlı olarak da değişmektedir. Asyalılarda, Amerika'da yaşayan siyahi bireylerde ve İngiltere'de yaşayan bireylere göre daha az görülmektedir. Amerika'da yaşayan bireyler ile yapılan bir çalışmada, siyahi kadınlarda görülme oranı \%8; beyaz ırktaki kadınlarda \%4,8 olarak bildirilmiştir (7).

Polikistik over sendromunun, ailesel/genetik geçişli olduğunu düşündüren bulgular gittikçe artmaktadır (19). Androjen reseptörü, seks hormonu bağlayıcı globulin sentezi (SHBG), insülin reseptörüne ait polimorfizmler hastalığ androjen üretimi yapan theca hücrelerinde CYP17A1 ekspresyonu ve artmış androjen üretimi görülmektedir (20). Pehlivanoğlu ve ark. tarafından 29 PKOS’lu bireyin anne ve kız kardeşleri üzerinde yapılan çalışmada, annelerin \%40'ında, kız kardeşlerin \%21'inde insülin direnci, artmış BKİ, bel çevresi, trigliserit ve düşük dansiteli lipoprotein (LDL) düzeyleri gözlemlenmiştir (21). 
Hipotalamik-hipofiz-over (HPO) ekseni, türlerin üreme yeterliliğinden ve hayatta kalmasından sorumlu olan senkronize ve sıkı bir şekilde düzenlenmiş bir ağdır. Androjen yüksekliği ve yumurtlama disfonksiyonu HPO eksen işlevini bozmaktadır (20). Hipotalamik-hipofiz-over ekseni tam olgunlaşmamış olan adölesan bireyler anovulatuvar döngülere sahip olma eğilimindedir. Bu nedenle adölesan bireylerde PKOS tanısının menarștan en az 2 yıl sonrasına ertelenmesi ve tanı konulurken insülin direnci olup olmadığına dikkat edilmesi önerilmektedir $(22,23)$. Tedavi planlamasında PKOS'lu bireylerde luteinleștirici hormon (LH), foliküler stimülan hormon (FSH), prolaktin, tiroid stimülan hormon (TSH), serbest ve bağlı testosteron seviyeleri gibi kan bulguları dikkate alınmaktadır (24).

\section{Polikistik Over Sendromu ve Obezite}

PKOS ile obezite ve insülin direnci arasında güçlü bir ilişki vardır (7). PKOS'lu bireylerde obezite görülme oranı \%30-75 arasında değişmekle birlikte ortalama \%50 olarak kabul edilmektedir $(8,18)$. İspanya, Çin, İtalya ve Amerika'da yapılan bir çalışmada, PKOS olgularının sırasıyla $\% 20, \% 43, \% 38$ ve $\% 69$ oranında obez olduğu gösterilmiștir (25).

Avusturyalı kadınlar arasında PKOS prevalansı ise \%17,8 olarak bulunmuştur (26). Amerika'da yapılan başka bir çalışma PKOS'lu kadınların \%40'ının obez olmadığını ancak sağlıklı BKİ aralığındaki PKOS'lu kadınların vücut yağ yüzdesi kriterlerine göre obez olduğunu bildirmiştir (9). 12-22 yaş arası 173 bireyin dahil edildiği bir çalışmada PKOS'lu bireylerin \%73'ünün hafif şişman veya obez olduğu bildirilmiştir (3). Vücut ağırlı̆̆ kazanımı sıklıkla oligomenore başlangıcı ve obezitenin patogenetik bir rolünü gösteren hiperandrojenizm ile görülmektedir (23). Obezite ile ilişkili metabolik anormallikleri açılamak için ileri sürülen teoriler, obezitenin PKOS gelişimindeki rolünü açıklamak için de kullanılabilmektedir. İlk teori adipokin teorisidir. Adipoz doku, adipokinler gibi pek çok hormonu salgılayan endokrin bir organ gibi fonksiyon göstermektedir. (18). Adipokinler santral olarak iştah ve enerji tüketimini düzenlerken, periferde insülin duyarlılı̆̆ı, oksidatif kapasite ve lipid alımını etkilemektedir (27). İnsülin direnci ile ters ilişkili olan adipokin türevi adiponektin seviyelerinin PKOS'lu bireylerde sağlıklı bireylere göre daha düşük olduğu görülmüştür. Diğer bir adipokin türevi olan leptin, adipoz doku miktarı ile ilişkili olup obez bireylerde daha yüksektir. Hiperleptinemi, insülin direnci ile ilişkilendirilmiş ve PKOS tanılı kadınlarda doğurganlık ile ters ilișkili bulunmuştur. Başka bir adipokin olan rezistin artışı insülin direncinin gelișimi ile bağlantılı olarak kardiyovasküler hastalık gelişiminde rol oynayabilmektedir (18). İkinci bir teori ise yağ dokusu genişletebilirlik teorisidir. Bu teori, lipotoksisite ve adipoz doku artışı ile sonuçlanmakta olup yağlar karaciğer, kaslar ve pankreas gibi diğer dokularda birikmeye başlamaktadır. Lipotoksisite ise insülin direncini ve daha sonra PKOS'lu kadınlarda yaygın olarak görülen hiperandrojenizmi tetiklemektedir (18). Hayvan modellerinde yapılan çalışmalarda, kronik hiperandrojenizmin besin alımını artırdığı gözlemlenmiștir. Enerji dengesini ve vücut ağırlığını korumak için iştah ve enerji alımının modülasyonu gereklidir. Gastrointestinal sistem, enerji homeostazında önemli rol oynamaktadır. Midede grelin, ince barsakta kolesistokinin, glukagon benzeri peptit-1 (GLP-1) ve peptit-YY (PYY) salınımı iştah durumunu etkilemektedir. Bu hormonlar, iştah düzenleyici hormonlar olarak bilinmekte ve enerji dengesinde önemli rol oynamaktadır (13).

Polikistik over sendromu; inflamasyon, tromboz, oksidatif stres, uyku apnesi, endotel disfonksiyonu ve arteriyel sertlik gibi kardiyovasküler risk belirteçleriyle de ilişkili bulunmuştur. İnsülin direnci ve abdominal obezite PKOS'ta metabolik bozukluk gelişme riskini arttırmaktadır (28). Polikistik over sendromu hastalarının yaklaşı yarısında insülin direnci, hiperlipidemi, hipertansiyon ve artmış inflamasyonla karakterize metabolik sendrom görülmektedir (5). Polikistik over sendromunda insülin direnci prevalansı \%50-75 aralığında değişmekle beraber bu bireylerde diyabet başlangıç yaşı sağlıklı bireylere göre 10 yaş daha erkendir (29). Polikistik over sendromlu bireylerde sağlıklı bireylere göre tip 2 diyabet görülme oranı 2 kat yüksek iken; BKİ değeri $30 \mathrm{~kg} / \mathrm{m}^{2}$ üzerine çıtı̆̆ı̆nda bu oran 10 kat daha yüksek olmaktadır (9). Obezite, PKOS'lu kadınların insülin direncini, hiperinsülinizmi, adipokin disfonksiyonunu ve subklinik inflamasyona yatkınlığı artırmanın yanı sıra gonadotropin sekresyonunun günlük ritmini değiştirmekte ve böylece androjen fazlalığına neden olmaktadır (30).

Polikistik over sendromu tedavisinde oral kontraseptif ve metformin kullanımı yaygindır. Oral kontraseptiflerin kullanımı menstrual döngüyü düzenlemekte ve androjen fazlalı̆̆ belirtilerini azaltmaktadır. Bununla birlikte oral kontraseptiflerin kullanımının obezite, insülin direnci, dislipidemi gibi metabolik anomalileri arttırıcı etki gösterebileceği bildirilmektedir (8). Metforminin ise birincil etki olarak hepatik glukoneogenezi baskıladığı, glukoz emilimini azalttığı, insülin duyarlılı̆ıını artırdığı ve periferik glukoz alımını arttırdığı düşünülmektedir. Hiperinsülinemi, PKOS patogenezinde önemli bir rol oynadığı için metformin müdahalesi PKOS'ta endokrin fonksiyonunu düzeltmek için kullanılmaktadır (13). Farklı çalışmalar ağırlık kaybı ve metformin tedavisinin, androjen seviyelerini azalttığını, hiperandrojenik belirti ve semptomları iyileştirdiğini göstermiştir. Hiperandrojenik PKOS hastaları üzerinde yapılan bir çalışmada; ağılık kaybı ve metformin tedavisinin insülin seviyelerini düşürerek 
androjen konsantrasyonlarını azaltabileceğini göstermiștir (28). Yaşam tarzı müdahalelerine ek olarak metformin kullanımının etkisinin araștırıldığı çalışmalarda, metformin kullanılan grupta adipoz doku ve vücut ağırlığının daha düşük ve menstrual döngülerin daha düzenli olduğu bildirilmiștir $(15,31)$.

\section{Polikistik Over Sendromu ve Ağırlık Yönetimi}

Polikistik over sendromunda obezite veya hafif şişman prevalansı \%40-60 arasında değişmektedir. Görülen obezite türü ise genellikle abdominal obezitedir $(2,7)$. Amerikan Üreme Tıbbı Derneği (American Society for Reproductive Medicine-ASRM) 2018 kılavuzlarına göre, PKOS'un ilk basamak tedavisi; diyet tedavisi ve egzersiz dahil olmak üzere yaşam tarzı müdahalesidir $(14,32)$. Obezitede; yağ dokusundan salınan serbest yağ asitleri ve tümör nekroz faktör (TNF)- $\alpha$ insülin direncinin patogenezinde önemli bir rol oynamaktadır. Obezitede; interlökin-6 (IL-6) ve interlökin-18 (IL-18) dahil olmak üzere diğer proinflamatuvar sitokinler de artış göstermektedir. Metabolik sendrom ve tip 2 diyabette olduğu gibi, plazma adiponektin seviyeleri azalırken, leptin ve rezistin artmaktadır (7). Bu nedenle, PKOS'ta tıbbi beslenme tedavisi ile ağırlı kaybı, kan glukozunun dengelenmesi, insülin direncinin düşürülmesi ve androjen düzeylerinin ayarlanması hedeflenmelidir (33).

Epidemiyolojik çalışmalar ve klinik deneyler, düşük dereceli kronik inflamasyonla ilişkili karbonhidrat tüketimi olmak üzere, PKOS patogenezinde rol oynayan bir dizi potansiyel diyet kaynaklı antiinflamatuvar ve pro-inflamatuvar bileșen tanımlamıștır. Hiperinsülinemi, hiperandrojenizm ve düșük dereceli inflamasyon ile birlikte sağlıksız bir beslenme planı, PKOS patofizyolojisi ile ilișkili metabolik risk faktörlerinin anahtar bileșeni olarak görülmelidir. Abdominal yağlanmanın yanı sıra PKOS ilişkili metabolik ve over disfonksiyonunun besin kaynaklı oksidatif stres ve inflamasyon ile artabileceği düşünülmektedir. Karbonhidratların inflamatuvar etkileri besinlerin glisemik indeks(Gí), glisemik yük ve farklı gıdalardaki karbonhidrata postprandiyal kan glukoz yanıtını ölçen bir indeks ile ilişkilendirilmektedir (34). Douglas ve ark. tarafından yapılan bir çalışmada 16 gün düşük karbonhidratlı bir diyetin (toplam enerjinin\%43'ü) açlı insülin konsantrasyonlarında önemli azalmalara neden olabileceğini ve bu durumun zamanla PKOS'lu kadınların üreme ve endokrin sonuçlar üzerine yararlı olabileceği gösterilmiştir (35). Bu nedenle tıbbi beslenme tedavisinin temelini, Gi yüksek karbonhidratların azaltılarak, Gİ düşük karbonhidratların arttırılması olușturmaktadır. Hastalığın düzeyine bağlı olarak özellikle obez PKOS'lu bireylerde enerjinin \%40'ını karşllayacak şekilde Gİ düşük karbonhidratlara yer verilmelidir. Besinlerin Gİ düşük olması, insülin direncinin azaltılmasında, dolayısıyla tokluk hissinin olușmasında önemli rol oynamaktadır (36).

Omega-3 yağ asitleri, PKOS ile ilișkili komplikasyonları gidermede umut verici bir ajandır. Glisemik ve hormonal homeostaz, anti-obezite ve anti-inflamatuvar etkiler, adipokin üretiminin düzenlenmesi ve endotel fonksiyonunun iyileștirilmesi dahil olmak üzere, omega-3 yağ asitlerinin PKOS'lu kadınlar üzerinde faydalı etkilerini gösterebileceği birçok mekanizma mevcuttur. PKOS'lu hastalarda omega-3 takviyelerinin etkisini araştıran çalışmalar, insülin direnci, dislipidemi, hiperandrojenizm ve metabolik göstergelerin düzenlenmesi dahil olmak üzere çok sayıda komplikasyon ve komorbiditede bir iyileșme bildirilmektedir (37). Sadeghi ve ark. tarafından yapılan üç randomize kontrollü çalışmanın metaanalizinde PKOS'lu kadınlarda 6-8 hafta süre ile 1,2-3,6 g omega-3 takviyesinin, kontrol gruplarına göre insülin direncinde azalmayı sağladığı gözlemlenmiștir (38). Polikistik over sendromlu kadınlarda omega-3 yağ asidinin etkinliğinin değerlendirmesi amacıyla 9 randomize kontrollü çalışmanın incelendiği metaanaliz çalışmasında, omega-3 takviyesinin insülin direncini iyileştirdiği, trigliserit ve total kolesterol seviyelerini azalttığını göstermiştir. Bununla birlikte, mevcut randomize kontrolü çalışmaların küçük örneklem sayısı ve kısa süre olmaları nedeniyle sınırlılıkları bildirilmektedir. Omega-3 yağ asitinin 6 aydan uzun süreli tedavisinin faydalarının açıklanması için daha fazla çalışmaya ihtiyaç duyulmaktadır (39).

Bu bilgiler ışığında tıbbi diyet tedavisi yaklaşımı olarak; düşük kalorili, şeker ve rafine karbonhidrat alımı sınırlandırılmış, düşük Gi besinlerden oluşan, doymuş yağ ve trans yağ içeriği azaltılmış, D vitamini, krom ve omega-3 yağ asitlerinden zengin bir beslenme modeli önerilmektedir (2). Bununla beraber, PKOS'ta ağırlık kaybı ve kaybedilen ağırlığın korunması zorlaşmaktadır (1). Polikistik over sendromlu bireylerin yeme alışkanlıkları ve yaşam kalitesinin incelendiği bir çalışmada, bireylerin ideal vücut ağırlığına ulaşmak için yeme davranışları benimsediği; ancak lezzetli yiyecekler karşısında aşırı yeme eğiliminde oldukları, stres gibi durumlara ve açlığa duyarlı oldukları saptanmıştır. İnfertilite ve vücut ağırlığı kaybı sorunu yaşayanların ise sağlıkla ilgili yaşam kalitesi puanlarının düșük olduğu gözlemlenmiștir (40). Başka bir çalışmada ise PKOS'lu kadınlarda magnezyum, demir, fosfor, retinol ve E vitamini alımlarının yüksek olduğu bildirilmiștir (33). Cutler ve ark. tarafından 87 PKOS tanılı ve 50 sağlıklı kadın ile yapılan çalışmada izokalorik ve karbonhidrat, yağ, protein alımları açısından benzer beslenmelerine rağmen PKOS'lu bireylerde daha yüksek BKİ bildirilmiştir (41). Yapılan bazı çalışmalarda ise 6 ay süre ile vücut 
ağırlığında \%5 azalma ile hafif vücut ağırlığı kaybının insülin direnci ve kan lipit düzeylerinde iyileşme, yumurta oluşumunun yeniden başlamasında önemli bir etkisi olduğu gösterilmiştir $(7,13,42)$.

Brown ve ark. tarafından 7767 bireyin incelendiği bir çalışmada, 556 kadında PKOS tespit edilmiş ve bu bireylerin yağ ve şeker alımını azaltma, düşük Gỉ diyeti, laksatif ilaçlar, açlık veya diüretik uygulamaları gibi yöntemler ile vücut ağırlığı yönetimi sağlamaya çalışmaya eğilimli oldukları gösterilmiştir. Bu diyet uygulamaları ile fiziksel aktivite, diyet kalitesi, protein alım yüzdesi, Gİ azalmalar ve yağ, doymuş yağ, lif alımında artışlar ile ilişkili olduğu belirlenmiştir. Buna ek olarak, alternatif vücut ağırlığı yönetimi uygulamaları diyet kalitesindeki düşüşlerle ilişkilendirilmiștir (43). Kısa süreli bir çalışmada, düşük karbonhidratlı (\% 43) ve doymamış yağ asitleri bakımından zengin (\% 17) diyetin etkileri, standart bir diyetle (düşük yağlı ve yüksek karbonhidrat) karşılaştııılmış ve düşük insülin seviyelerini ortaya çıkarmıştır. Fakat insülin duyarlılı̆ı̆ında veya cinsiyet hormonlarında önemli bir değişiklik bildirilmemiştir (2). 16 hafta süre ile uygulanan düşük Gİ, yüksek Gİ, yüksek protein, düşük protein gibi farklı diyet uygulamalarının PKOS'a etkisinin araştırıldığı bir çalışmada, diyet protein içeriğindeki ılımlı artış (günlük enerji alımının \%17-19'u) ve Gi'teki hafif azalmaların vücut ağırlı̆̆ kaybının sürdürülmesinde iyileșme sağladığı gözlemlenmiş̧tir (44). Son yıllarda düşük (200 g/gün altı, 50-150 g/gün karbonhidrat) ve çok

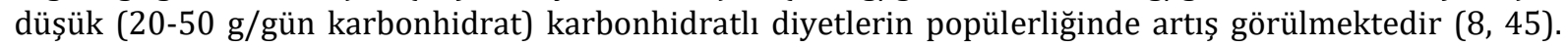
Düşük karbonhidrat diyeti uygulamalarının vücut ağırlığı azaltıcı etkisi olduğu ve obez PKOS hastalarında infertilite tedavisini destekleyici olduğunu gösteren çalışmalar olsa da PKOS'un klinik semptomlarının iyileștirilmesi üzerindeki etkisi henüz kanıtlanamamıștır $(8,14)$. 26 PKOS tanılı obez hasta ile enerji kısıtlı yüksek protein (\%30 protein, $\% 40$ karbonhidrat, $\% 30$ yağ) ve yüksek karbonhidrat (\%15 protein, \%55 karbonhidrat, \%30 yağ) içerikli diyet uygulanması sonucunda yüksek protein diyeti grubunda $3,7 \pm 1,9 \mathrm{~kg}$,

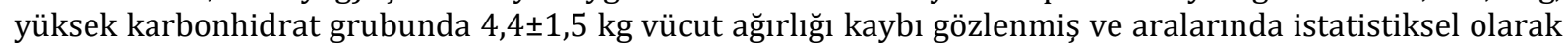
anlamlı bir farklılık bulunamamıștır (46). Benzer şekilde, yüksek protein (\%30 protein ve \%40 karbonhidrat) ile düşük protein (\%15 protein ve \%55 karbonhidrat) diyeti uygulanan hafif şişman 28 PKOS tanılı bireyde vücut ağırlı̆̆ında düşük protein grubunda $6,9 \pm 0,8 \mathrm{~kg}$ ve yüksek protein grubunda $8,5 \pm 1,1 \mathrm{~kg}$ kayıp görülmüş olup; iki grup arasında vücut ağırlı̆̆ı kaybında anlamlı farklılık bulunamamıştır. Diyet kompozisyonundan bağımsız olarak \%7,5 ağıllık kaybı, yüksek dansititeli lipoprotein (HDL) düzeyinde $\% 10$ artış ve insülin direncinde iyileşmeler görülmüsstür (33). Mehrabani ve ark. tarafından yapılan tek kör randomize bir çalışmada, 60 PKOS'lu hafif şişman ve obez kadına geleneksel hipokalorik diyet (günlük enerji alımının \%15'i proteinlerden gelen bir zayıflama diyeti) ile modifiye hipokalorik diyet (günlük enerji alımının \%30'u proteinlerden gelen düşük Gíli bir zayıflama diyeti) 12 hafta süre ile uygulanmıştır. Vücut ağırlı̆̆ kaybı iki grupta benzer bulunurken, testosteron düzeyleri müdahale grubunda 1,78 $\pm 0,32 \mathrm{ng} / \mathrm{mL}$ 'den $1,31 \pm 0,26 \mathrm{ng} / \mathrm{mL}$ 'ye ve kontrol grubunda ise $1,51 \pm 0,12 \mathrm{ng} / \mathrm{mL}$ 'den $1,15 \pm 0,11 \mathrm{ng} / \mathrm{mL}$ 'ye düşmüştür $(\mathrm{p}<0,001)$. FSH, LH ve kan lipit düzeylerinde değişiklik olmaz iken, müdahale grubunda insülin ve insülin direnci düzeyi düşüş göstermiştir (6). Panagiotakos ve ark. yaptığı çalışmada kırmızı et tüketiminin hiperglisemi, hiperinsülinemi düzeyleri ile pozitif ilişsili olduğunu saptanmıştır (47). Yüksek protein diyeti uygulamaları göz önüne alındığında dikkate alınması gereken diğer önemli nokta ise artan meyve, sebze ve diyet posası alımının kardiyovasküler hastalık, diyabet ve kansere karşı koruyucu etkileri olurken; hayvansal kaynaklı yüksek protein tüketiminin genel popülasyonda malignite riskini arttırmakta olduğudur (2).

Bir meta-analizde 327 hastayı kapsayan 8 randomize kontrollü çalışma incelenmiş ve yağ oranı \%35'in altında olan düşük karbonhidratlı diyetlerin (\%45'ten az karbonhidrat oranı) daha olumlu etkileri olduğu; BKI, insülin direnci, FSH ve SHGB düzeylerini istatistiksel olarak anlamlı şekilde düşürdüğü gözlemlenmiştir (14). NIH kriterlerine göre PKOS tanılı, BKİ değeri $25-45 \mathrm{~kg} / \mathrm{m}^{2}$ arasında olan $20-45$ yaş arası bireyler ile yapılan bir çalışmada $46 \mathrm{~g}$ badem veya $36 \mathrm{~g}$ ceviz içeren 1800 kalorilik bir diyet programı 6 hafta süre ile uygulanmış ve ağırlıkta istatistiksel olarak anlamlı bir azalma olmamıştır. Ceviz tüketimi insülin duyarlılığını artırırken, glukoz intolerans testlerinde farklılık görülmemiştir. Hem ceviz hem badem tüketimi ile adiponektin ve leptin düzeylerinde artış sağlandığı gözlemlenirken, SHGB oranı ceviz tüketimi ile $\% 12,5$ ve badem tüketimi ile $\% 16$ oranında artmıștır. Buna ek olarak, LDL kolesterol düzeyi ceviz tüketimi ile \%6, badem tüketimi ile $\% 10$ azalmıștır (5).

Yeterli ve dengeli besin ögeleri alımı PKOS hastalarında vücut ağırlığı yönetiminde oldukça önemlidir. D vitamininin biyolojik olarak aktif formu olan $1,25(\mathrm{OH})_{2}$ vitamin $\mathrm{D}$, insülin direncine aracllı edebilen proinflamatuvar sitokinlerin salınımını baskılayarak insülin sentezini artırabilmektedir. Polikistik over sendromunda insülin direnci ve hiperinsülinemi overde androjen sentezini arttırmakta ve SHBG düzeyini azaltmaktadır. Obezite ise D vitamininin biyoyararlanımını azalmakta ve hiperandrojenizm, hirsutizm, infertilite gibi bazı PKOS bulgularının görülme riskini arttırmaktadır (48). 


\section{Fenotip}

Genel İsimlendirme

$\begin{array}{lll}\text { Fenotip A } & \text { Oligoamonere } & \\ & \text { - Polikistik over morfolojisi } & \text { Klasik PKOS } \\ & \bullet & \text { Hiperandrojenizm }\end{array}$

Fenotip B

Fenotip C

Fenotip D
- Oligoamonere

- Hiperandrojenizm

- Polikistik over morfolojisi

- Hiperandrojenizm

- Oligoamonere

- Polikistik over morfolojisi
Klasik PKOS

Ovulatuvar PKOS

Non-hiperandrojenik PKOS

Polikistik over sendromlu infertilite sorunu yaşayan kadınlarda D vitamini düzeylerini ve D vitamini takviyesinin infertilite üzerine etkisini saptamak amacıyla yapılan bir çalışmada, PKOS hastalarının \%83'ünde D vitamini eksikliği görülürken, \%35'inde ciddi derecede eksiklik saptanmış olup serum 25-

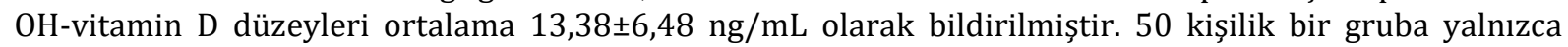
metformin tedavisi ve 50 kişilik bir gruba ise metformin tedavisine ek olarak 6 ay boyunca $100 \mathrm{mg} / \mathrm{gün}$ kalsiyum ve 100000 IU/ay D vitamini takviye edilmiştir. Kalsiyum ve D vitamini takviyesi alan PKOS hastalarının \%74'ünde D vitamini eksikliğinin düzeltildiği ve BKİnin yaklaşık 1 birim kadar anlamlı düzeyde azaldığı gösterilmiştir. Sonuç olarak, PKOS'lu infertil kadınlarda kalsiyum ve D vitamini takviyesinin vücut ağırlığı kaybı, folikül olgunlaşması, menstrüasyon döngüsü düzenliliği ve hiperandrojenizmin gelişmesi üzerine olumlu etkileri olduğu gözlemlenmiștir (28).

İnositol, insülin sinyal iletiminde rolü olan bir besin takviyesi olarak kullanılabilmektedir. İnositolün PKOS'un metabolik ve biyokimyasal bileșenlerini değiştirmedeki rolü hakkında sınırlı kanıtlar mevcut olmasına rağmen menstrual döngü ve yumurtlamayı iyileştirilebileceği düşünülmektedir (22). Le Donne ve ark. tarafından yapılan çalışmada 43 hafif şişman veya obez PKOS tanılı kadın randomize olarak 3 gruba ayrılmış ve 6 ay boyunca takip edilmiştir. 1. gruba yalnızca 1200 kalorilik diyet, 2. gruba diyet ile birlikte $400 \mathrm{mcg} /$ gün folik asit ve $4 \mathrm{~g}$ miyo-inositol, 3. gruba ise diyet ve $400 \mathrm{mcg} /$ gün folik asit takviyesine ek olarak 1,1 g miyo-inositol ve 27,6 mg D-kiroinositol verilmiştir. Diyet ve folik asit takviyesine ek olarak 1,1 g miyo-inositol ve 27,6 mg D-kiroinositol verilen grupta ağırlık kaybı ve yağsız kütle artmış, adipoz doku ise azalmıştır (49).

Glikoz ve lipid metabolizması üzerindeki etki mekanizmaları tam olarak belirlenmemiş olan kromun eksikliğinin insülin direnci ve diyabet ile ilişkili olduğu bildirilmektedir. Kromun, insülin reseptörlerinin sayısını ve insülin bağlanmasını arttırdığı öne sürülmüştür. Krom, insülin reseptörü- $\beta$ kinaz aktivitesini, insülin sinyali veren pI3-kinaz ve Akt'nin aşağı akış efektörlerinin aktivitesini ve hücre yüzeyine Glut-4 translokasyonunu arttırdığı gösterilmiştir. Krom takviyesinin insülin duyarlılığını artırarak yumurtalık hormonları ve androjen seviyelerini etkileyebileceği görülmektedir (50). Randomize kontrollü çift kör bir çalışmada 8 hafta boyunca krom pikolinat desteği verilmesinin PKOS’lu kadınlarda serum insülin ve insülin direnci düzeyini düşürdüğü, insülin duyarlılığını arttırdığı görülmüştür. Buna ek olarak, krom pikolinat desteği ile kan lipit profillerinde iyileşme olduğu gözlemlenmiştir (51). Ashoush ve ark. tarafından gerçekleştirilen çift-kör randomize kontrollü çalışmada 6 ay süre ile müdahale grubuna $(n=50)$ $1000 \mu \mathrm{g}$ krom pikolinat ve kontrol grubuna (n=50) plasebo kapsül desteği uygulanmıştır. Krom pikolinat desteği, insülin direncini azaltmak ve yumurtlamayı uyarmak için PKOS'ta faydalı bulunmuştur(52). 
Yaşlanma, sigara ve alkol tüketimi, yüksek kafein alımı, stres ve çevresel kirleticiler gibi pek çok faktör doğurganlığı etkilemektedir(53). Genel popülasyonda kafein tüketimi ile infertelite arasındaki ilişki net değildir (54). Kafein, hormon düzeylerine değiștirerek korpus luteum fonksiyonunu ve ovülasyonu etkilemektedir. Kafein alımı doğurganlığın azalması için bir risk faktörü olarak görülmektedir. Bu nedenle, PKOS'lu bireylerde günde 500 mg'dan fazla kafein alımı infertilite riskini arttırdığı bildirilmektedir (2). Ancak kafein alımı ve infertilite iliş̧kisinin incelendiği kontrollü klinik çalışmaların sistematik derlemesi düşük ( $\leq 100 \mathrm{mg} /$ gün), orta ( $\geq 200 \mathrm{mg} /$ gün) ve yüksek ( $\geq 400 \mathrm{mg} /$ gün) dozda kafein alımının infertilite riskini artırmadığını gösteren düşük kaliteli kanıtlar sunmaktadır (54). 20-29 yaş arası 11088 kadından oluşan popülasyon tabanlı bir kohort çalışmasında gebelik öncesi günlük farklı oranlarda (günde $75 \mathrm{mg}$ altı, 75-300 mg, 301-500 mg, 501-900 mg, $900 \mathrm{mg}$ üstü) kafein alımı ile spontan düşük arasındaki ilişki incelenmiş olup; hamilelikten önce yüksek miktarda kafein alımı, spontan düşük riskinde artışla ilişkili bulunmuştur (55). Adenosin, adrenerjik, kolinerjik, GABA veya serotonin reseptörü ile etkileşime girerek merkezi sinir sistemine etki eden kafeinin diyetle maruziyetinin teratojenik olmadığı ancak artmış spontan düşük ve fetal büyüme geriliği riskinden sorumlu olduğu bildirilmektedir (56).

\section{Sonuç}

Yaygın endokrin bir bozukluk olan PKOS görülme oranı gün geçtikçe artmaktadır. Polikistik over sendromunun kardiyovasküler hastalıklar, insülin direnci, diyabet, obezite gibi hastalıklar ile ilişkili olduğu da düşünüldüğünde, hastalı̆̆ın tedavisi oldukça önem taşımaktadır. Doğurganlık çağındaki kadınlara medikal tedavinin yanı sıra vücut ağırlığı kaybı ve verilen vücut ağırlığının korunması önerilmektedir. Polikistik over sendromlu kadınlarda 6 ay süre ile ılımlı vücut ağırlığı kaybı (\%5) sağlandığında bile kronik hastalık risklerinde azalmalar görülmektedir. Polikistik over sendromu tıbbi beslenme tedavisinde düşük kalorili, şeker ve rafine karbonhidrat alımı sınırlandırılmış, düşük Gíl'li besinlerden oluşan, doymuş yağ ve trans yağ içeriği azaltılmış, D vitamini, krom ve omega-3 yağ asitlerinden zengin bir beslenme modeli önerilmektedir. PKOS'lu bireylerde günlük alınan enerjinin \%55'inin karbonhidrat, \%15'inin proteinden sağlanması, yağdan gelen enerjinin ise \%30 ile sınırlandırılması ve düzenli fiziksel aktivite (150 dk/hafta) yapılması önerilmektedir. Tüm bu veriler ele alındığında, PKOS tedavisinde vücut ağırlı̆̆ı yönetiminin sağlanması ve korunması için önemli bir basamak olan tıbbi beslenme tedavisinin iyi planlanması gerekmektedir.

\section{Kaynakça}

[1] Lim S, Smith CA, Costello MF, MacMillian F, Moran L, EE C. Barriers and facilitators to weight management in overweight and obese women living in Australia with PCOS: a qualitative study. BMC Endocr Disord. 2019; 19: 106.

[2] Faghfoori Z, Fazelian S, Shadnoush M, Goodarzi R. Nutritional management in women with polycystic ovary syndrome: A review study. Diabetes Metab Syndr. 2017; 11: 429-32.

[3] Baer TE, Milliren AC, Walls C, DiVasta AD. Clinical variability in cardiovascular disease risk factor screening and management in adolescent and young adult women with polycystic ovary syndrome. J Pediatr Adolesc Gynecol. 2015; 28(5);317-23.

[4] Ecklund LC, Usadi RS. Endocrine and Reproductive Effects of Polycystic ovarian syndrome. Obstet Gynecol Clin N Am. 2015; 42(1): 55-65.

[5] Kalgaonkar S, Almario RU, Gurusinghe D, Garamendi EM, Buchan W, Kim K et al. Differential effects of walnuts vs almonds on improving metabolic and endocrine parameters in PCOS. Euro J Clin Nutrition. 2011; 65: 386-93.

[6] Mehrabani HH, Salehpour S, Amiri Z, Farahani SJ, Meyer BJ, Tahbaz F. Benefical effects of a highprotein, low glycemic load hypocaloric diet in overweight and obese women with polycystic ovary syndrome: a randomized controlled intervention study. J Am Coll Nutr. 2012; 31(2):117-25.

[7] Farshchı H, Rane A, Love A, Kennedy RL. Diet and nutrition in polycystic ovary syndrome(PCOS):Pointers for nutritional management. J Obstet Gynaecol. 2007; 27(8): 762-73.

[8] Rollyn M, Ornstein MD, Nancy M, Copperman MS, Marc S, Jacobson MD. Effect of weight Loss on menstrual function in adolescents with polycystic ovary syndrome. J Pediatr Adolesc Gynecol. 2011; 24: 161-65.

[9] Pedersen SD. Metabolic complications of obesity. Best Pract Res Clin Endocrinol Metab. 2013; 27: 17993.

[10] Kadıoğlu M, Kızılkaya N. Polikistik Over Sendromu ve Hemşirelik Yaklaşımı. F.N. Hem. Derg. 2013; 21(3): 187-97. 
[11] Keskin H, Timur Ö, Kaya Y, Utlu M, Yıldız F, Ademoğlu E ve ark. Polikistik over sendromlu hastalarda artmış ürik asit düzeyleri ve klinik ile ilişkisi. Turkish Journal of Clinics and Laboratory. 2016; 7(2): 34-8.

[12] Bozdag G, Yıldız BO. Interventions for the metabolic dysfunction in polycystic ovary syndrome. Steroids. 2013; 78: 777-81.

[13] Ma J, Lin TC, Liu W. Gastrointestinal hormones and polycystic ovary syndrome. Endocrine. 2014; 47:668-78.

[14] Zhang X, Zheng Y, Guo Y, Lai Z. The effect of low carbohydrate diet on polycystic ovary syndrome: A meta-analysis of randomized controlled trials. Int J Endocrinol 2019.

[15] Naderpoor N, Shorakae S, de Courten B, Misso ML, Moran LJ, Teede HJ. Metformin and lifestyle modification in polycystic ovary syndrome: systematic review and meta-analysis. Hum Reprod Update. 2016; 22(3): 408-9.

[16] Kite C, Lahart IM, Afzaı I, Brown JE, Broom DR, Randeva H et al. Exercise, or exercise and diet fort he management of polycystic ovary syndrome: a systematic review and meta-analysis. Syst Rev. 2019; 8: 51.

[17] Azziz R. Polycystic Ovary Syndrome. Obstet Gynecol. 2018;132(2): 321-35.

[18] Kahal H, Atkin SL, Sathyapalan T. Phamacological Treatment of Obesity in patients with polycystic ovary syndrome. J Obes. 2011.

[19] Arusoğlu G, Sökülmez Kaya P. Polikistik Over Sendromu: Uzun Dönem Sağlık Riskleri ve Yaşam Tarzı Değişikliğinin Etkileri. Turkiye Klinikleri J Health Sci 2016;1(1): 55-67.

[20] Witchel SF, Oberfiel SE, Peria AS. Polycystic Ovary Syndrome: Pathophysiology, Presentation and Treatment with Emphasis on Adolescent Girls. J Endocr Soc. 2019; 3(8): 1545-73.

[21] Pehlivanoğlu V, Koç Bebek A, Akalın A, Süer N. Polikistik Over Sendromlu Hastaların Reprodüktif Çă̆daki Anne ve Kız Kardeşlerinde Metabolik Parametrelerin Değerlendirilmesi. J Clin Obstet Gynecol. 2011;21(3): 148-54.

[22] Jacob S, Balen AH. How Will the New Global Polycystic Ovary Syndrome Guideline Change Our Clinical Practice?. Clin Med Insights Reprod Health . 2019; 13: 1-7.

[23] Eleftheriadou M, Stefanidis K, Lykeridou K, İliadis L, Michala L. Dietary habits in adolescent girls with polycystic ovarian syndrome. Gynecol Endocrinol. 2015; 31(4): 269-71.

[24] Screening and Management of the Hyperandrogenic Adolescent: ACOG Committee Opinion Summary, Number 789. Obstet Gynecol. 2019;134(4): 888-89.

[25] Moran LJ, Pasquali R, Teede HJ, Hoeger KM, Norman RJ. Treatment of obesity in polycystic ovary syndrome: a position statement of the androgen excess and polycystic ovary syndrome society. Fertil Steril 2009; 92: 1966-82.

[26] Ee C, Smith C, Costello M, MacMillan F, Moran L, Baylock B et al. Feasibility and acceptability of a proposed trial of acupuncture as an adjunct to lifestyle interventions for weight loss in Polycystic Ovary Syndrome: a qualitative study. BMC Complement Altern Med. 2018; 18(1): 298.

[27] Motor S, Keskin MC, Dokuyucu R. Obezite ve adipokinler. Mustafa Kemal Üniv. Tıp Derg. 2014; 5(18): 34-45.

[28] Firouzabadi R, Aflatoonian A, Modarresi S, Sekhavat L,Taheri SM. Therapeutic effects of calcium \& vitamin D supplementation in women with PCOS. Complement Ther Clin Pract. 2012; 18(2):85-8.

[29] Jiang G, Cheung LP, Zhang Y, Quan J, Goggins W, Woo J, et al. Progression of glucose intolerance and cardiometabolic risk factors over a decade in Chinese women with polycystic ovary syndrome: A case-control study. PLoS Medicine. 2019; 16(10).

[30] Luque-Remirez M, Escobar-Morreale HF. Polycystic Ovary Syndrome as a paradigm for prehypertension, prediabetes and preobesity. Curr Hypertens Rep. 2014; 16: 500.

[31] Glueck CJ, Aregawi D, Winiarska M, Agloria M, Luo G, Sieve L, et al. Metformin-diet ameliorates coronary heart disease risk factors and facilitates resumption of regular menses in adolescents with polycystic ovary syndrome. J Pediatr Endocrinol Metab. 2006; 19(6): 831-42.

[32] Moran LJ, Noakes M, Clifton P, Buckley J, Brinkworth G, Thomson R, et al. Predictors of Lifestyle Intervention Attrition or Weight Loss Success in Women with Polycystic Ovary Syndrome Who Are Overweight or Obese. Nutrients. 2019; 11(3):492.

[33] Moran LJ, Ko H, Misso M, Marsh K, Noakes M, Talbot M. Dietary composition in the treatment of polycystic ovary syndrome: a systematic review to inform evidence-based guidelines. J Acad Nutr Diet. 2013; 113(4): 520-45.

[34] Barrea L, Marzullo P, Muscogiuri G, Di Somma C, Scacchi M, Orio F et al. Source and amount of carbohydrate in the diet and inflammation in women with polycystic ovary syndrome. Nutrition research reviews. 2018; 31(2): 291-301. 
[35] Douglas CC, Gower BA, Darnell BE, Ovalle F, Oster RA, Azziz R. Role of diet in the treatment of polycystic ovary syndrome. Fertil Steril. 2006: 85; 679-688.

[36] Lydic M. Dietary Approaches and Alternative Therapies for Polycystic Ovary Syndrome. Current Nutrition \& Food Science. 2008: 4; 265-281.

[37] Salek M, Clark CC, Taghizadeh M, Jafarnejad S. N-3 fatty acids as preventive and therapeutic agents in attenuating PCOS complications. EXCLI journal. 2019: 18; 558.

[38] Sadeghi A, Djafarian K, Mohammadi H, Shab-Bidar S. Effect of omega-3 fatty acids supplementation on insulin resistance in women with polycystic ovary syndrome: Meta-analysis of randomized controlled trials. Diabetes \& Metabolic Syndrome: Clinical Research \& Reviews. 2017: 11(2); 157-162.

[39] Yang K, Zeng L, Bao T, Ge J. Effectiveness of omega-3 fatty acid for polycystic ovary syndrome: a systematic review and meta-analysis. Reproductive Biology and Endocrinology. 2018: 16(1); 1-13.

[40] Turner-McGrievy G, Davidson CR, Billings DL. Dietary intake, eating behaviors, and quality of life in women with polycystic ovary syndrome who are trying to conceive. Hum Fertil (Camb). 2015; 18(1): 16-21.

[41] Cutler DA, Pride SM, Cheung AP. Low intakes of dietary fiber and magnesium are associated with insulin resistance and hyperandrogenism in polycystic ovary syndrome: A cohort study. Food Sci Nutr. 2019; 7 (4): 1426-37.

[42] Ryan DH, Yockey SR. Weight Loss and Improvement in Comorbidity: Differences at 5\%, 10\%, 15\%, and Over. Curr Obes Rep. 2017;6(2): 187-94.

[43] Brown WJ, Moran LJ, McNaughton SA, Joham AE, Teede HJ. Weight management practices associated with PCOS and their relationships with diet and physical activity. Hum Reprod. 2017;32(3): 669-78.

[44] Larsen TM, Dalskov SM, van Baak M, Jebb SA, Papadaki A, Pfeiffer AFH, et al. Diets with high or low protein content and glycemic index for weight-loss maintenance. N Engl J Med. 2010; 363(22): 2102-13.

[45] Westman EC, Feinman RD, Mavropoulos JC, Vernon MC, Volek JS, Wortman JA, et al. Lowcarbohydrate nutrition and metabolism. Am. J. Clin. Nutr. 2007: 86(2); 276-284.

[46] Stamets K, Taylor DS, Kunselman A, Demers LM, Pelkman CL, Legro RS. A randomized trial of the effects of two types of short-term hypocaloric diets on weight loss in women with polycystic ovary syndrome. Fertil Steril. 2004: 81(3);630-37.

[47] Panagiotakos DB, Tzima N, Pitsavos C, Chrysohoou C, Papakonstantinou E, Zampelas A, Stefanadis

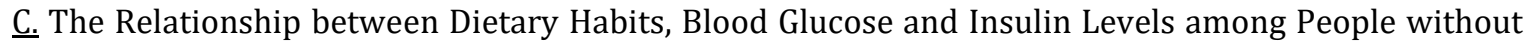
Cardiovascular Disease and Type 2 Diabetes; The ATTICA Study. Rev Diabet Stud. 2005: 2(4); 208215.

[48] Baysal I, Köseler E. Polikistik Over Sendromunda D Vitamininin Rolü. BÜSBİD. 2017; 2(1): 15-26.

[49] Le Donne M, Metro D, Alibrandi A, Papa M, Benvenga S. Effects of three treatment modalities (diet, myoinositol or myoinositol associated with D-chiro-inositol) on clinical and body composition outcomes in women with polycystic ovary syndrome. Eur Rev Med Pharmacol Sci. 2019; 23(5): 2293301.

[50] Maleki V, Izadi A, Farsad-Naeimi A, Alizade'den M. Chromium supplementation does not improve weight loss or metabolic and hormonal variables in patients with polycystic ovary syndrome: A systematic review. Nutrition Research. 2018: 56; 1-10.

[51] Asemi Z, Jamilian M. Chromium supplementation and the effects on metabolic status in women with polycystic ovary syndrome: A randomized, double-blind, placebo-controlled trial. Ann Nutr Metab 2015; 67(1): 42-8.

[52] Ashoush S, Abou-Gamrah A, Bayoumy H, Othman N. Chromium picolinate reduces insulin resistance in polycystic ovary syndrome: Randomized controlled trial. J Obstet Gynaecol Res. 2016: 42(3); 279-85.

[53] Silvestris E, Lovero D, Palmirotta R. Nutition and Female İnfertility: An Interdependent Correlation. Front Endocrinol (Lausanne). 2019: 10; 346.

[54] Bu FL, Feng X, Yang XY, Ren J, Cao HJ. Relationship between caffeine intake and infertility: a systematic review of controlled clinical studies. BMC Womens Health. 2020: 20(1);125.

[55] IS Tolstrup, SK Kjaer, C Munk, LB Madsen, B Ottesen, T Bergholt, et al. Does caffeine and alcohol intake before pregnancy predict the occurrence of spontaneous abortion? Hum Reprod. 2003: 18(12);2704-10.

[56] Brent RL, Christian MS, Diener RM. Evaluation of Reproductive and Developmental Risks of Caffeine. Birth Defects Research. 2011: 92;152-187. 